\title{
المحسنات اللفظية في سورة الرحمن (دراسة تحليلية بلاغية)
}

\author{
Muhammad Syahran \\ Sekolah Tinggi Agama Islam Negeri Majene \\ Email: muhammad.syahran.m.m@gmail.com
}

\begin{abstract}
ملخص
تهدف هذه الأطروحة إلى معرفة المحسنات اللفظية وأغراضها في سورة الرحمن. وأما مناهجها المستخدمة، فهي تنقسم إلى

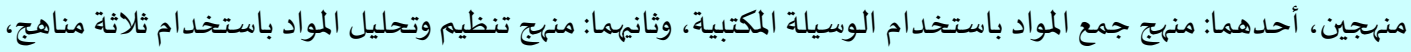

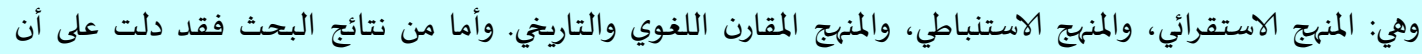

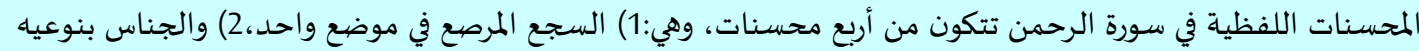

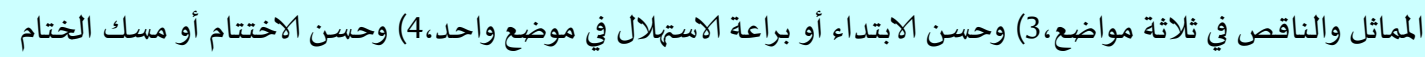
في موضع واحد، فصار مجموع هذه المحسنات اللفظية أربعة في ستاة مواضع. وكذلك دلت على أن أغراض المحسنات اللفظية في سورة الرحمن تكون في أربعة أغراض، وهي: 1) الإعجاز اللغوي، 2) والإعجاز الموسيقي أو النغمي، 3) والحِكَم 4) وعلم

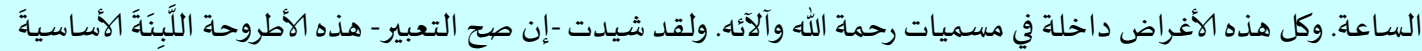

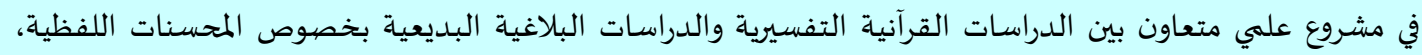

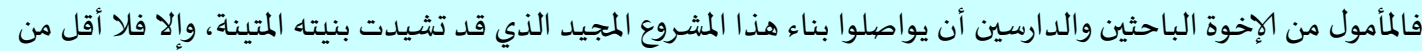

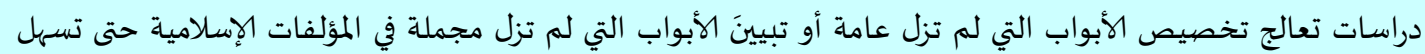

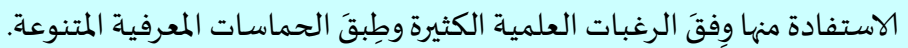

الكلمات المفتاحية: المحسنات اللفظية، سورة الرحمن، دراسـة تحليلية بلاغية
\end{abstract}

\begin{abstract}
Abstrak
Tujuan artikel ini adalah untuk mengetahui al-Muhassināt al-Lafżiyyah dan tujuantujuannya dalam Surah al-Rahmān. Metode yang digunakan untuk mengatur dan menganalisis data ada tiga: pendekatan induktif, pendekatan deduktif, dan metode linguistik historis komparatif. Adapun hasil penelitian telah menunjukkan bahwa alMuhassināt al-Lafżiyyah dalam Surah al-Rahmān terdiri dari empat Muhassināt: 1) al-Saja' alMurașsa' di satu tempat, 2) al-Jinās dengan dua jenisnya al-Mumāsil dan al-Nāqișdi 3 tempat dan 3) Barā'ah al-Istihlāl, dan 4) Husnu al-Khitām, sehingga total al-Muhassināt al-Lafżiyyah dalam Surah al-Rahmān adalah empat pada enam tempat. Hasil penelitian Ini juga menunjukkan bahwa tujuan dari al-Muhassināt al-Lafziyyah dalam Surah al-Rahmān ada dalam empat tujuan: 1) mukjizat linguistik, 2) mukjizat musik atau irama, 3) hikmahhikmah 4) dan ilmu tanda-tanda kiamat. Semuanya ini termasuk dalam kategori Rahmat dan Nikmat karunia Allah swt. Diharapkan bagi saudara-saudara, para peneliti, dan cendekiawan, untuk melanjutkan proyek yang mulia ini yang telah terbangun strukturnya yang kokoh. Minimal ada studi dan kajian yang mengkhusukan bab-bab yang masih bersifat umum atau merinci pembahasan yang masih global dalam literatur Islam sehingga mudah diambil manfaatnya sesuai dengan keinginan ilmiah yang beragam dan latar belakang pengetahuan yang berbeda.
\end{abstract}

Kata kunci: al-Muhassināt al-Lafžiyya; Surah al-Rahmān; Studi analisis balāgah. 


\section{مقلدمة}

قال ابن خلدون في المقدمة: كان الزخشري قد ألف الكشاف وهو محاولة على فهم وتفسير الآيات القرآنية بوسيلة علم البلاغة أو في منظور علم البلاغة، فبلغ إلى بحلية البعض من إعجاز القرآن

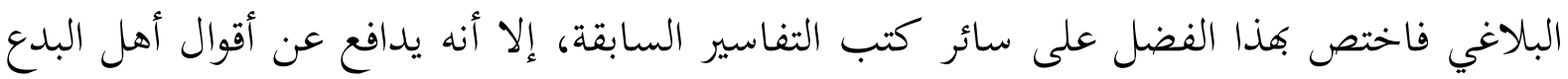
عند اقتباسها من كتاب الله عز وجل بوجوه البلاغة، ولأجل ذلك يبتعد عنه كثير من أهل السنة والجماعة مع كثرة علومه في البلاغة. 21

ثم من العلماء المتأخرين من فج في تفسيره منهج الزخشري مثل وهبة بن مصطفى الزحيلي في كتابه التفسير المنير في العقيدة والشريعة والمنهج لأنه قسم تفسير كل آية حسب أنواع العلم، ومنها البلاغة.

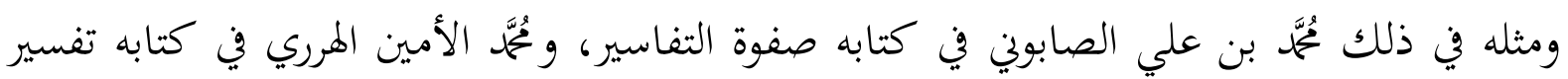
حدائق الروح والريحان في روابي علوم القرآن.

والمباحث البلاغية وبالأدق المباحث البديعية وبخصوص المحسنات اللفظية في تلك التفاسير موجودة بكثرة، ولكنها ما زالت مختلطة بين علم المعاني والبيان والبديع، فلا يخصص كل في مكانه بل ينضم بعضه إلى بعض. فهذه الأطروحة التي سيقدمها الباحث تعالج ما تركته هذه التفاسير، لأنها ستجعل

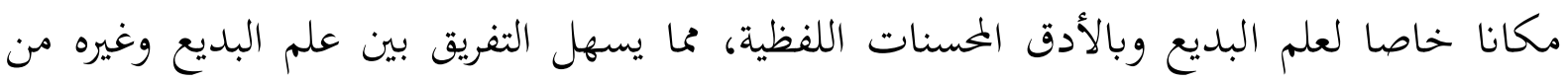
العلوم البلاغية الأخرى بل بين المحسنات المعنوية والمحسنات اللفظية.

وأما الكتب أو الدراسات أو الرسائل العلمية التي تعالج العناصر البلاغية بشكل عام في سورة الرحن،

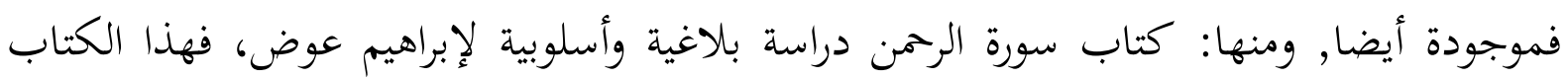

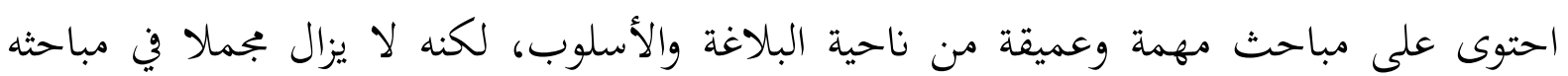
البلاغية، فلا يفرق بين المعاني والبيان والبديع بل لا يذكر فيه الأغراض البلاغية ولا سيما المحسنات اللفظية بشكل مستقل.

1 عبد الرمن بن خلدون، مقدمة ابن خلدون(بيروت: دار الفكر، 1431 هـ - 2001 )، ج. 1، ص. 555- 
المحسنات اللفظبة في سورة الرحمن (دراسة تحليلية بلاغية)

وتعثر الباحث على رسالة الدكتوراه في جامعة علاء الدين الإسلامية الحكومية مكاسر سنة 2013 م

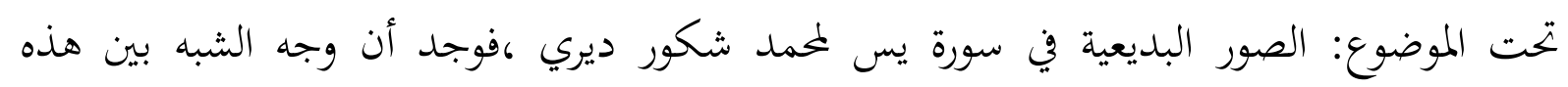

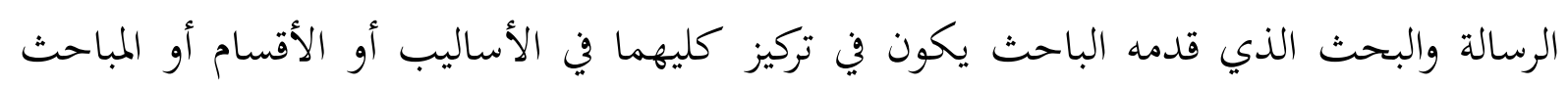

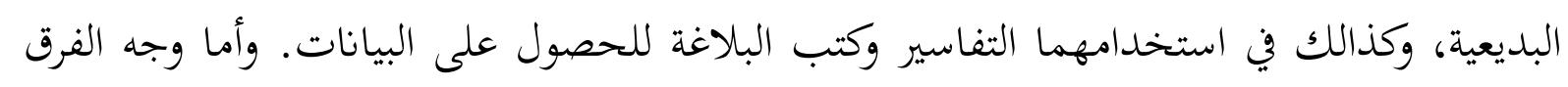

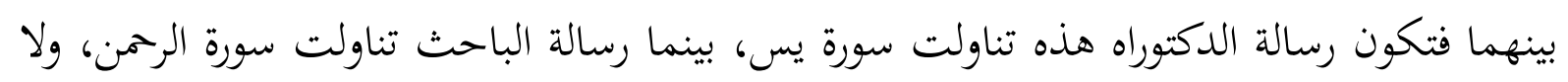

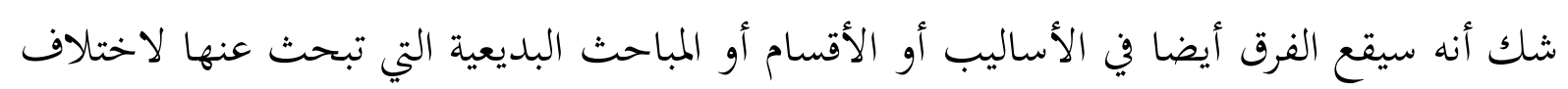
السورة. وكذا يقع الفرق أيضا في منهج البحث، فرسالة الدكتوراه هذه تستخدم منهج التحليل

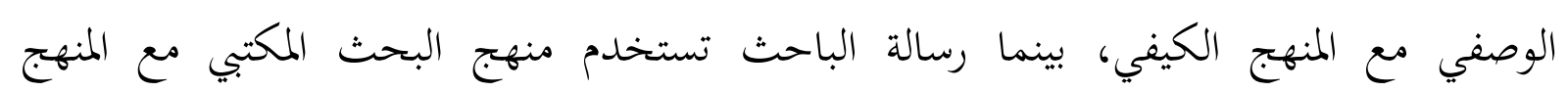
الاستقرائي والاستنباطي والمقارن.

وكذلك تعثر الباحث على رسالة الماجستير في قسم تعليم اللغة العربية بجامعة علاء الدين الإسلامية

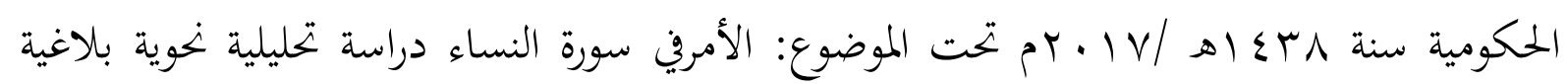
لشمس الدين، ونستطيع القول بأن هذه الرسالة من حيث وجه الشبه ووجه الفرق بينها وبين هذه

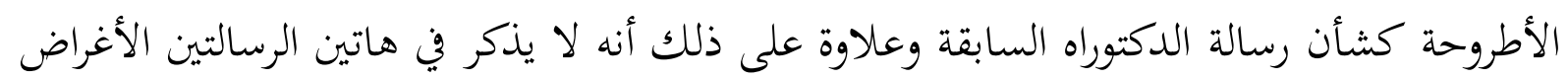
البلاغية وبالأصح أغراض المحسنات اللفظية.

نعم، قد اطلع الباحث على مجلة ديوان وهي مجلة محكمة لقسم اللغة العربية وآدابها لكلية الآداب

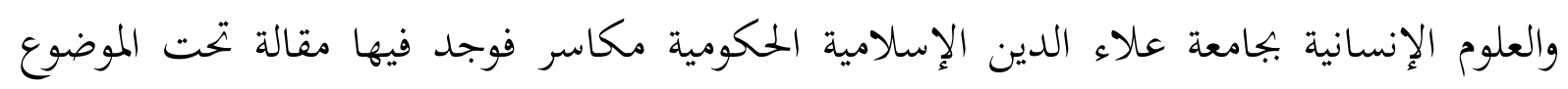

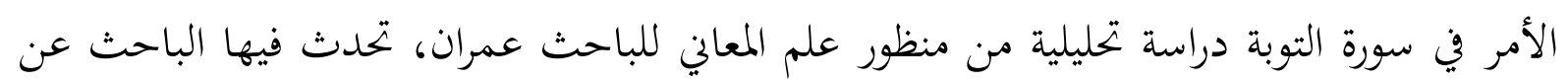
معاني صيغ الأمر في سورة التوبة فحصل على معنى الإباحة والإهانة والتهديد والتسوية. 3

ولا أبالغ إن قلت إن المعاني غير الأغراض، لأن الأغراض أعمق منها، فالمعاني من الوسائل للحصول

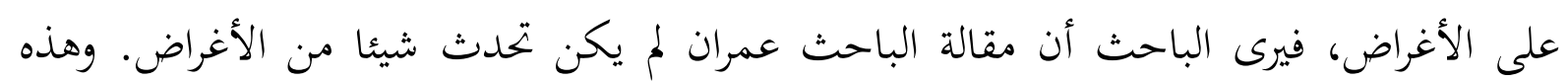

3عمران، الأمر في سورة التوبة دراسة تحليلية من منظور علم المعاني (بجلة ديوان، ج. 4، الرقم 2، 2018)، ص. 
الأغراض هي المشكلة الأساسية والمميزة الحميدة -وإن لم تكن وحيدة- في مقالة الباحث تحت العنوان: المحسنات اللفظية في سورة الرحمن (دراسة تحليلية بلاغية).

فمن الجمدير بالذكر أن تلك الكتب والدراسات والبحوث قد تحدثت كثيرا عن العناصر البلاغية

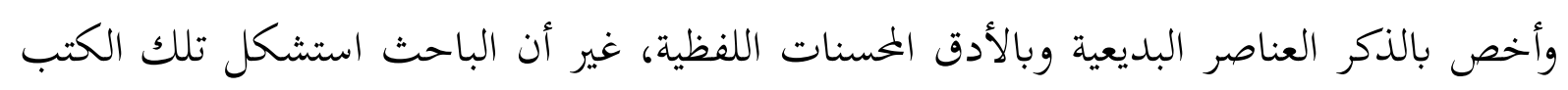

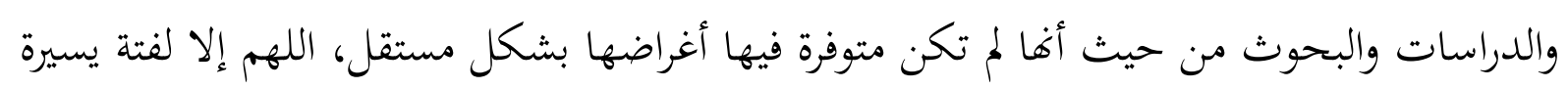
وهي لا تشفي العليل ولا تروي الغليل فيما يخص أغراض العناصر البلاغية وبالأدق المحسنات اللفظية. والحاجة إلى هذه الأغراض تحوجنا قبل كل شيء إلى ذكر المحسنات اللفظية كمنطلق أساسي

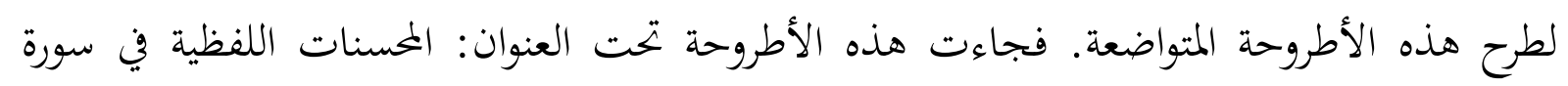

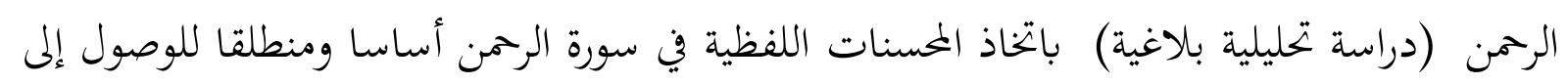
أغراضها التي نتحدث عنها في مقامها المناسب.

\section{المحسنات اللنظية في سورة الرحمن}

السجع المرصع غير المتكلف

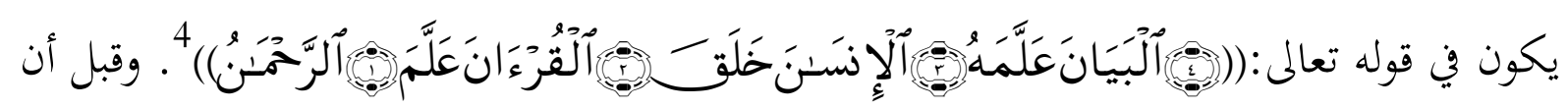
يوضح الباحث ماهية السجع المرصع غير المتكلف، فمن الأهمية بمكان إيضاح تعريف السجع بالإطلاق. فقال السيوطي: السجع مأخوذ من سجع الحمام، وهو عند أهل الفن تواطؤ الفاصلتين 5 من النثر على حرف واحد....

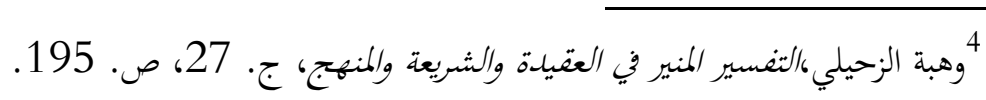

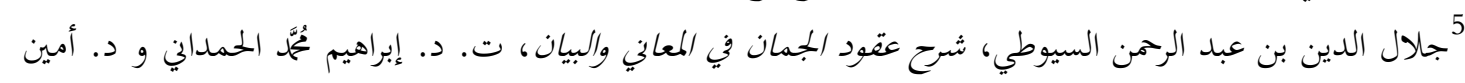


المحسنات اللفظبة في سورة الرحمن (دراسة تحليلية بلاغية)

وأما السجع المرصع فهو أحد أقسام السجع الثلاثة، وهو ما كان في الأولى مقابلا لما في الثانية وزنا

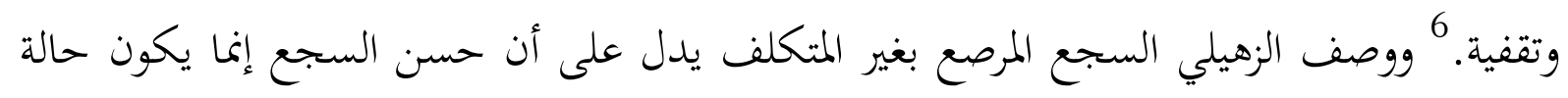
غير متكلف، فإذا كان متكلفا زال حسنه وبماله.

وقال الهاشمي: السجع هو توافق الفاصلتين في الحرف الأخير، وأفضله ما تساوت فقره، وهو ثلاثة

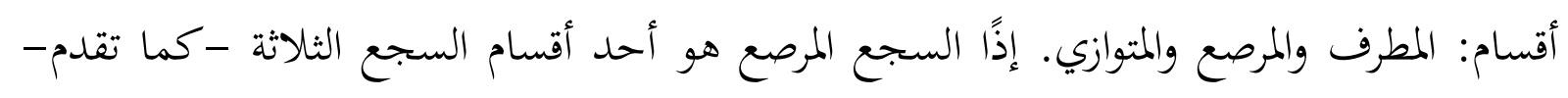
وهو ما كان فيه ألفاظ إحدى الفقرتين كلها أو أكثرها مثل ما يقابلها من إموات الفقرة الأخرى وزنا

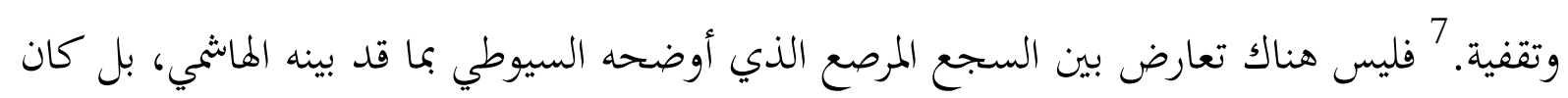
الهاشمي مؤيدا لما قد أوضحه السيوطي.

فوزن وتقفية كل من كلمة الرحم، والقرآن، والإنسان، والبيان في الآية المذكورة متقابلتان، ذلك لأن

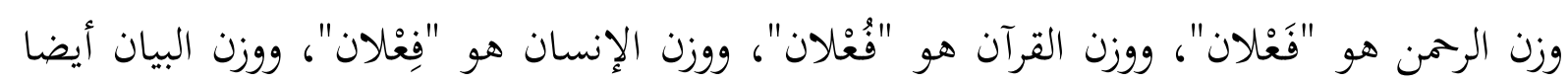

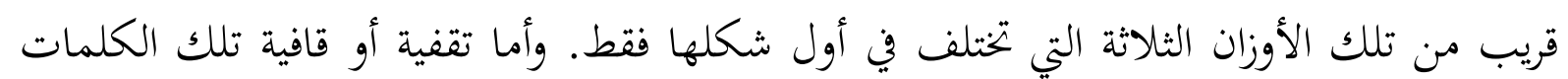
كلها بالألف والنون، وهذا هو أهم الاعتبارات في السجع.

الجناس في ثلاثة مواضع

\section{الجناس الناقص أو جناس الاشتقاق لتغير الشكل والحروف}

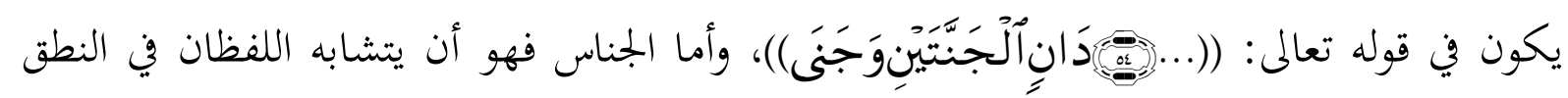
ويختلفا في المعنى، وهو نوعان، النوع الأول: تام وهو ما اتفق فيه اللفظان في أمور أربعة هي: نوع

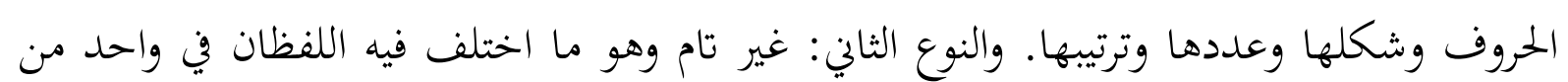

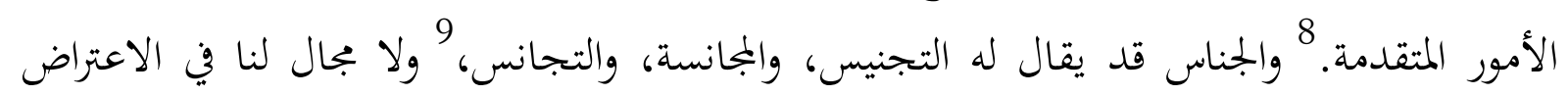

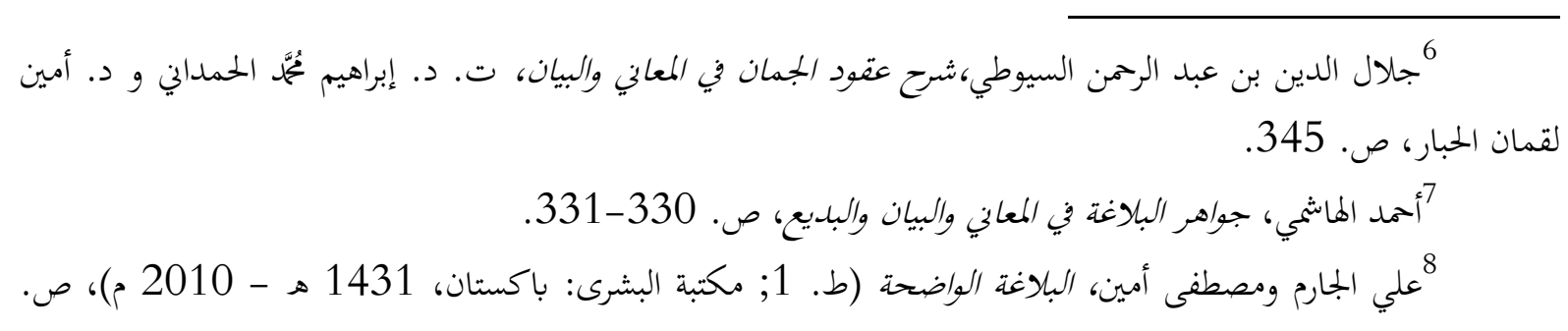


على اختلاف تلك الأسامي بعد فهم اتفاق المعاني، وقد سامح إمام علم البديع ابن المعتز العباسي من أراد أن يأتي باسم آخر غير ما قد سماه به، بل سامح من أراد أن يأتي بفن من فنون البديع غير ما قد أتى به هو، كما هو المشار إليه في قوله ما نصه: "ولعل بعض من قصر عن السبق إلى تأليف هذا الكتاب ستحدثه نفسه وتمنيه مشاركتنا في فضيلته، فيسمي فنا من فنون البديع بغير ما سميناه به، أو يزيد في الباب من أبوابه كلاما منثورا..."10

وقال السيوطي: من أنواع البديع اللفظية الجناس بين اللفظين، وهو تشابهما في اللفظ... قال في كنز البراعة: ولم أر من ذكر فائدته، وخطر لي أهفا الميل إلى الإصغاء، فإن مناسبة الألفاظ تحدث ميلا وإصغاءا إليهما، ولأن اللفظ المشترك إذا حمل على معنى ثم جاء والمراد به آخر، كان للنفس تشوق إليه.... ومن أنواع الجناس، الناقص بأن يختلفا (اللفظان) في عدد الحروف.... 11

\section{جناس الإضمار}

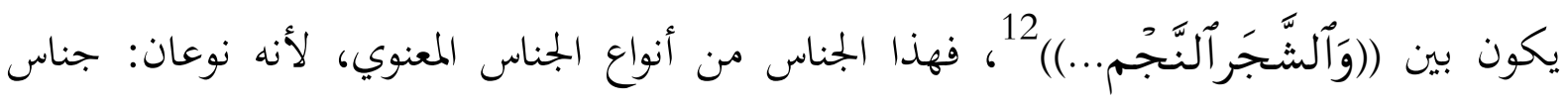
إضمار وجناس إشارة، والجناس في قوله تعالى: ((وَألشَّجَرَألَّجُمب...)) جناس الإضمار، وهو أن يأتي بلفظ يكضر في ذهنك لفظا، وذلك اللفظ المخضر يراد به غير معناه بدلالة السياق. 13 ذلك لأن لفظ النجم يحضر في الذهن بأنه كوكب من كواكب السماء أو نجم من نجوم السماء، إلا أن دلالة السياق وهي لفظ الشجر الواقع بعده تدل على أن المراد هو ليس بكوكب من كواكب السماء أو نجم من

9جلال الدين بن عبد الرحمن السيوطي، شرح عقود الجمان في المعاني والبيان، ت. د. إبراهيم مُحَّة الحمداني و د. أمين

لقمان الحبار، ص. 325.

10 أبو العباس عبد الله بن المعتز، كتاب البديع، شرحه وحققه عرفان مطرجي (ط. 1; بيروت: مؤسسة الكتب الثقافية،

http://www.noor-book.com/badi-1 (9 April 2018) هـ - 1433

11 جلال الدين بن عبد الرحمن السيوطي، شرح عقود الجمان في المعاني والبيان،تات. د. إبراهيم عُمَّمَ الحمداني و د. أمين

لقمان الحبار، ص. 332-325.

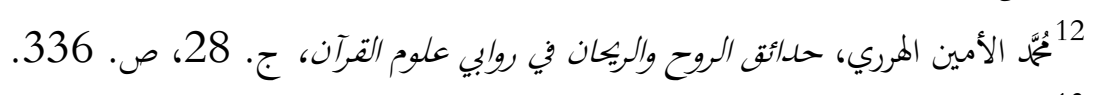

13 أحمد الهاشمي، جواهر البلاغة في المعاني والبيان والبلديع، ص. 
المحسنات اللفظبة في سورة الرحمن (دراسة تحليلية بلاغية)

نجوم السماء، بل المراد هو النبات الذي لا ساق له لقرينة الشجر الذي يدل على النبات التي لها ساق.

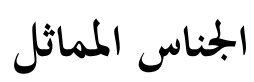

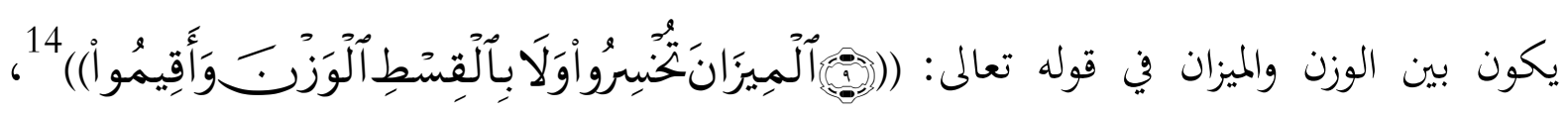
وكما تقدم أن الجناس هو تشابه اللفظين في النطق واختلافهما في المعنى، وهو إما لفظي وإما معنوي.

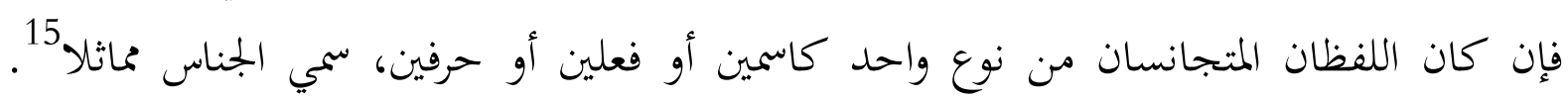

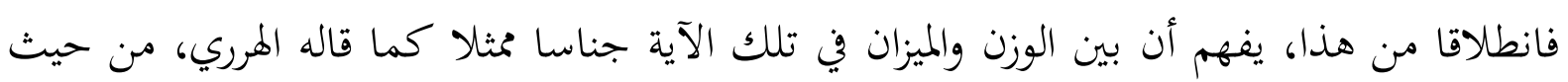

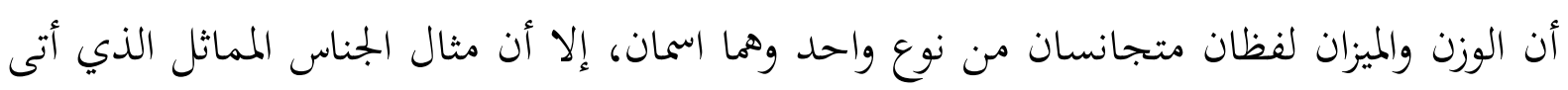
به العلماء في كتبهم لا يحصل فيه شيء من الاختلاف في اللفظين، لا بزيادة حرف أو نقصانه، إنما

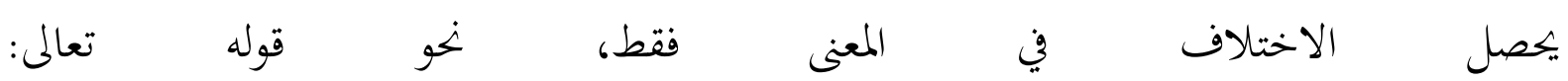

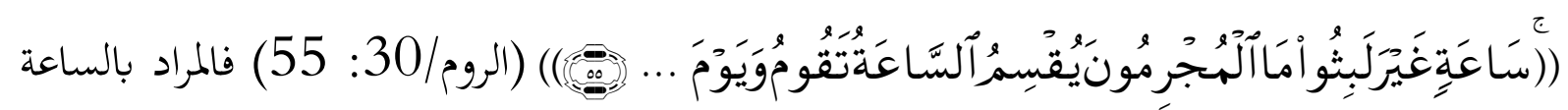
الأولى يوم القيامة، وبالساعة الثانية المدة من الزمان 16.

ففي نظر الباحث أن بين الوزن والميزان في تلك الآية عدم توفر الشروط لتسميته بالجناس المماثل، لا سيما أن السيوطي ذكر في شرح عقود الجمان: أنه قيل، لم يقع من الجناس المماثل في القرآن غير هذه

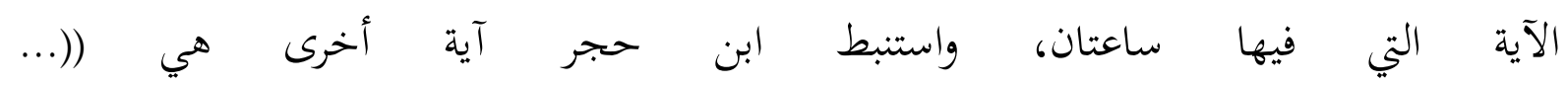

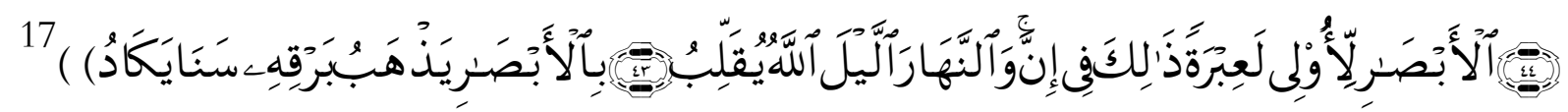

$$
\begin{aligned}
& \text { 14 مُمَّه الأمين الهرري، حدائق الروح والريحان في روابي علوم القرآن، ج. 28، ص. } 310 .
\end{aligned}
$$

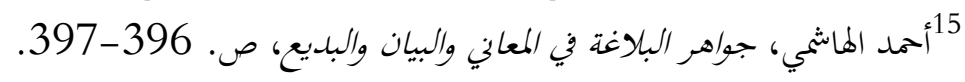

$$
\begin{aligned}
& \text { 16 أحمد الهاشمي، جواهر البلاغة في المعاني والبيان والبلديع، ص. } 397
\end{aligned}
$$

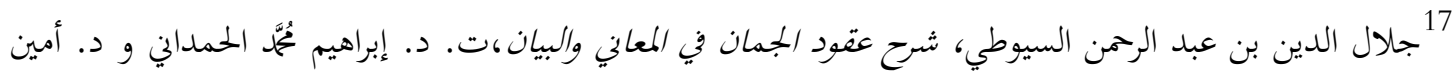

$$
\begin{aligned}
& \text { لقمان الحبار، ص. }
\end{aligned}
$$


فيرى الباحث أن بين الوزن والميزان في تلك الآية جناسا غير تام أو ناقصا، لأن الجناس غير التام أو

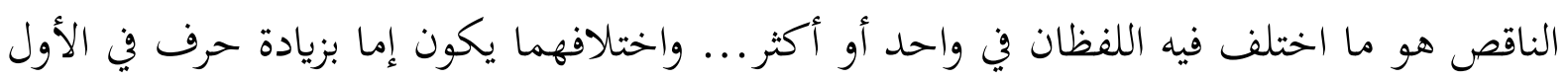

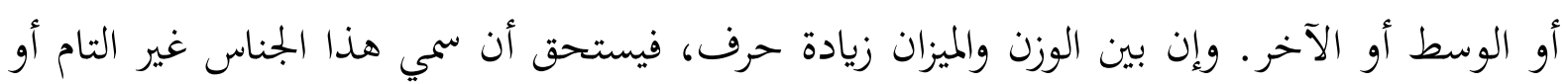

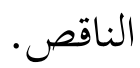

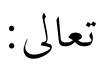

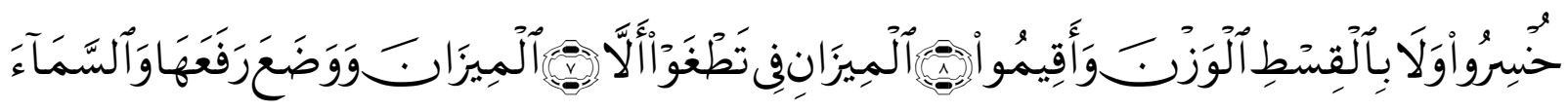

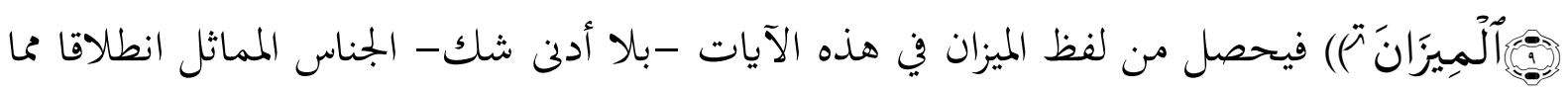
ذكره السيوطي في استباط ابن حجر

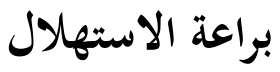

وهي ما يشير إليها البقاعي بقوله في تفسيره: وصدرها (أي سورة الرمن) بالاسم الدال على عموم

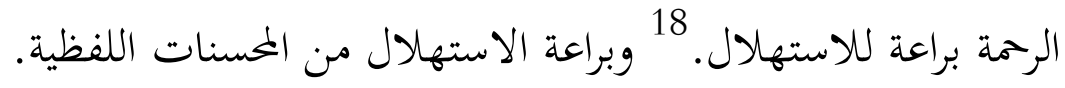

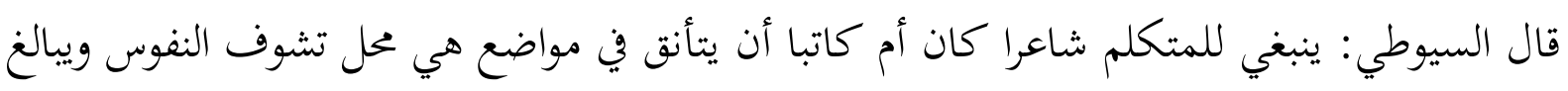
في تحسينها بأعذب لفظ وأجزله وأرقه وأسلسه وأحسنه نظما وسبكا وأصحه معنى وأوضحه وأخلاه

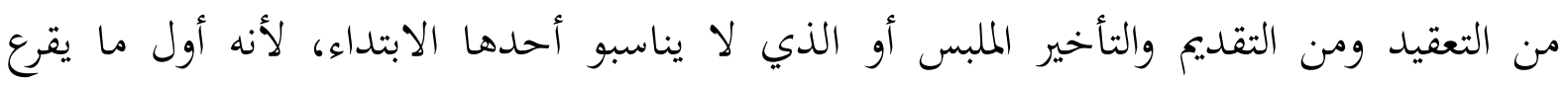

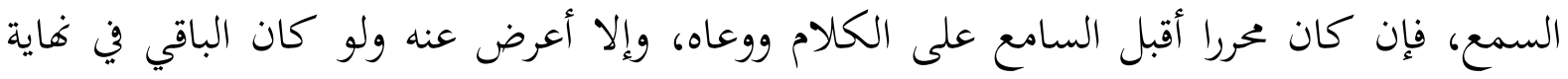

$$
\text { 18 إبراهيم بن عمر البقاعي، نظم الدرر في تناسب الآيات والسور، ج. 19، ص. } 140 .
$$

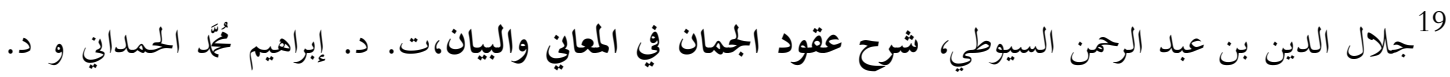


الدحسنات اللفظبة في سورة الرحمن (دراسة تحلبلية بلاغية)

فكل من السيوطي والهانمي ذكر حسن الابتداء أو براعة الاستهلال أو براعة المطلع في كتابيهما،

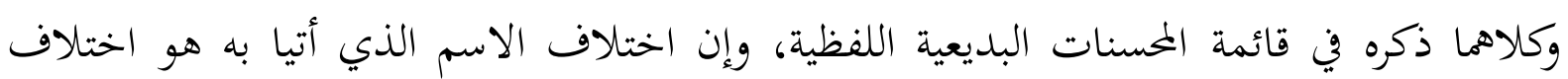
لفظي، لأن المعنى الذي أراداه منه سِيَّانِ.

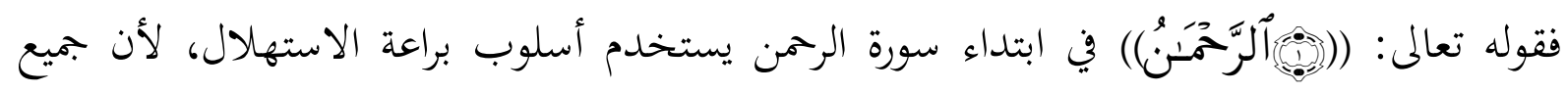
المباحث والمحاور التي بينها الله بعد هذا الافتتاح، يتعلق بعموم الرحمة، وقد دل قوله تعالى:

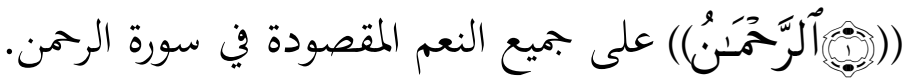

$$
\begin{aligned}
& \text { وحسن الاختتام أو حسن الانتهاء أو حسن الختام }
\end{aligned}
$$

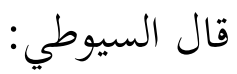

\section{بختمه فهو البليغ الأحسن}

\section{وإن يجئ في الانتهاء مؤذن}

هذا آخر المواضع التي يجب التأنق فيها، لأنه آخر ما يعيه السامع ويرسم في الذهن، فإن كان حسنا

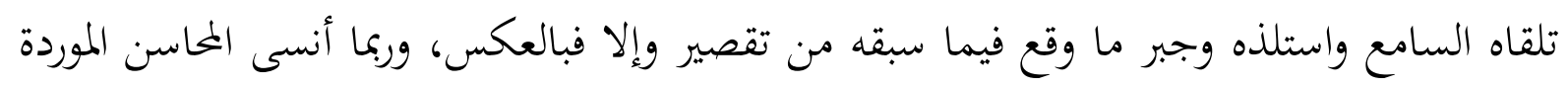
فيما سبق.

وقال الهانمي: حسن الانتهاء أو حسن الختام هو أن يجعل المتكلم آخر كلامه عذب اللفظ، حسن

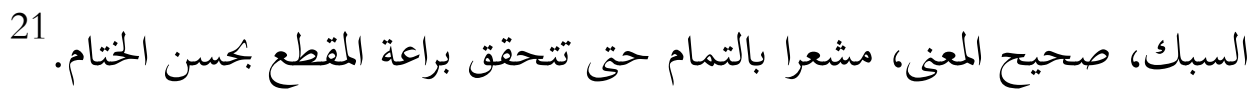

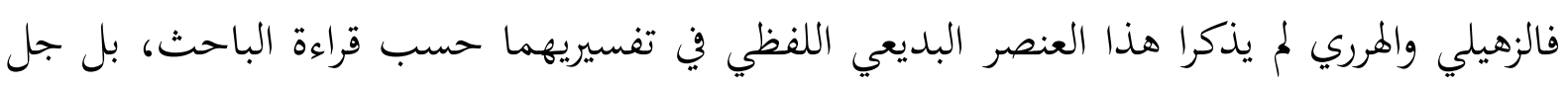
العلماء والباحثين لم يلفتوا النظر إليه بصريح القول، سوى ما ذكره البيقاعي نقلا عن الرازي، وهو قوله: ... وقد انعطف آخر السورة على أولها على وجه أعم... 22

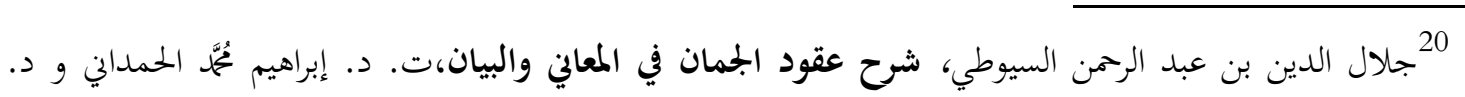
أمين لقمان الحبار، ص.

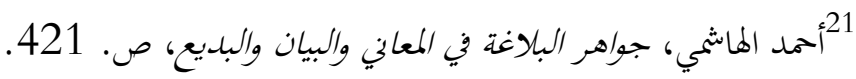

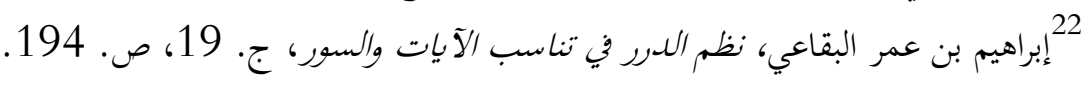




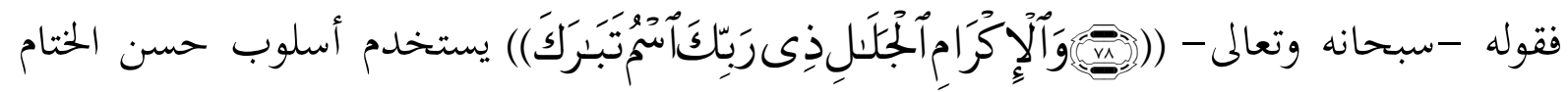
أو مسك الختام، وذلك لأن جميع الآلاء والنعم التي قد أنعمها الله على الخلق وبينها في مواضع مختلفة

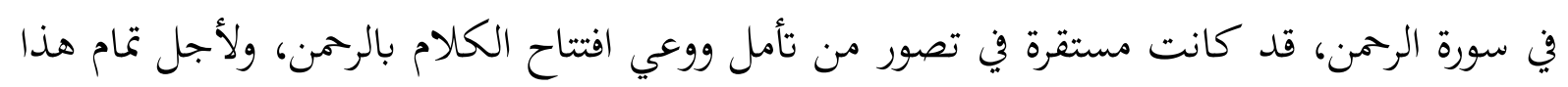
التأمل والوعي، فلا بد من اختتام يناسب الافتتاح حتى يتم الكلام صورة ومعنى، وحتى يتنبه القارئ أن الكلام قد انتهى، فلا ينتظر البيان الآخر. أغراض المحسنات اللفظية في سورة الوحمن الإعجاز اللغوي

قال الرازي: ... والميزان ذكره الله تعالى ثلاث مرات، كل مرة بمعنى آخر، فالأول هو الآلة ووضع

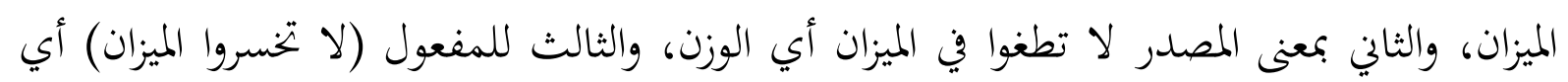

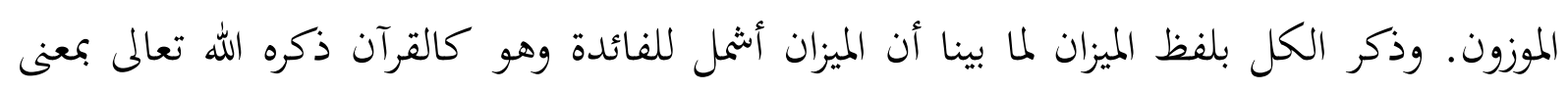

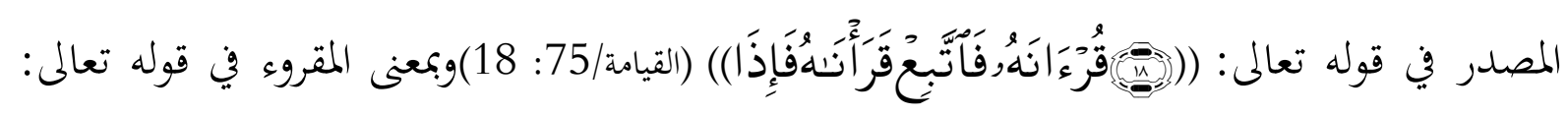

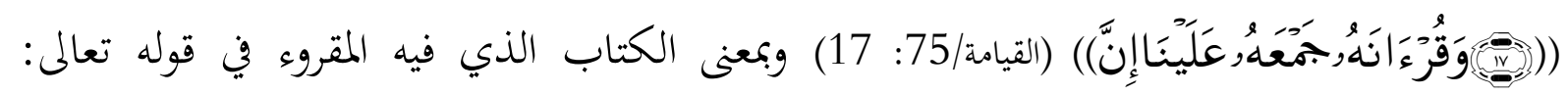

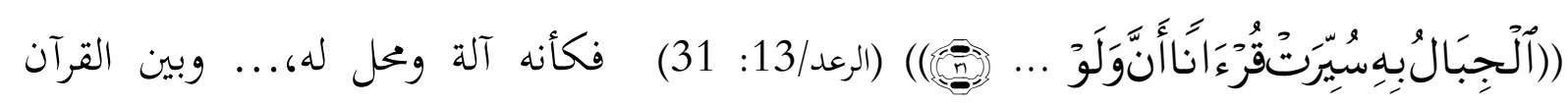
والميزان مناسبة، فإن القرآن فيه من العلم مالا يوجد في غيره من الكتب، والميزان فيه من العدل مالا يوجد في غيره من الآلات 23.

فيمكن للباحث أن يستنتج خلاصة هذه الأغراض بأن تكرار لفظ الميزان في مقام التأكيد والتشديد

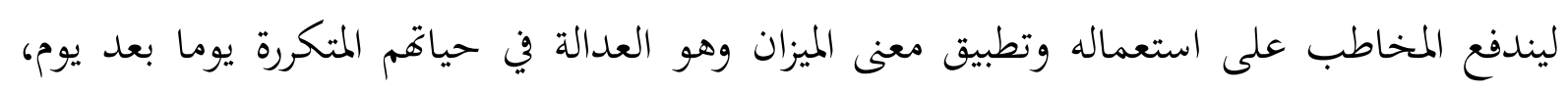

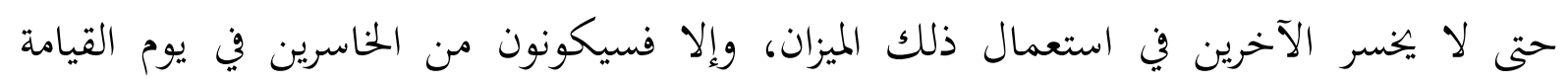

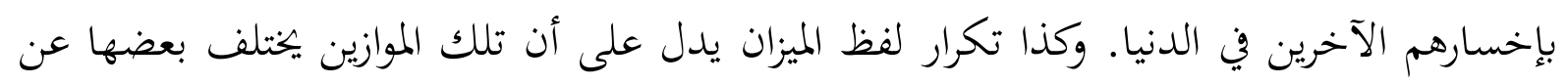
بعض، فلا بد من إظهاره لا إضماره، لأن الإضمار يدل على نفس الشيء المذكور من قبل، ولا

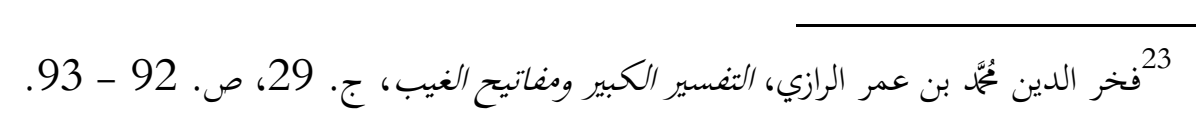


المحسنات اللفظبة في سورة الرحمن (دراسة تحليلية بلاغية)

يؤتى بلفظ آخر له معنى مرادف للفظ الميزان، لأن شمولية دلالة لفظ الميزان لا يقوم مقامها لفظ آخر.

\section{الإعجاز الموسيقي أو النغمي}

قال عبد الكريم الخطيب في التفسير القرآني للقرآن: الرحمن، والقرآن، والإنسان، والبيان، وبحسبان،

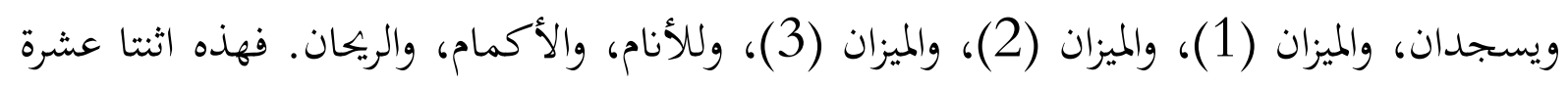

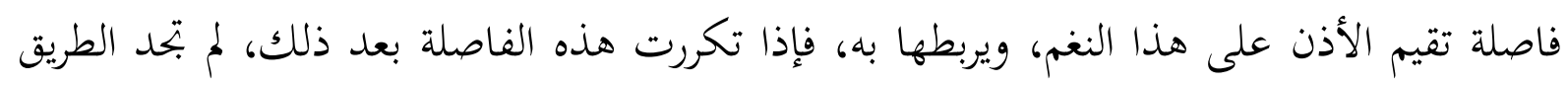

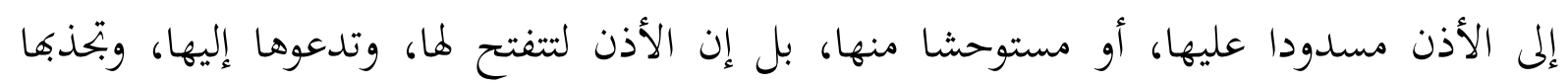
نغوها.

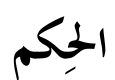

وأما ل

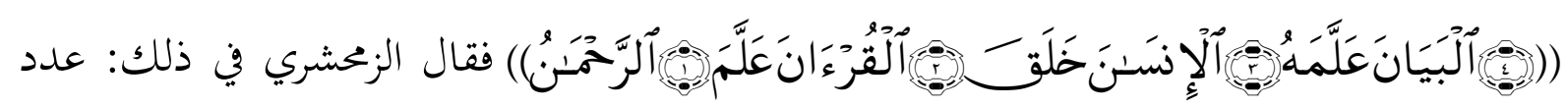
الله -عز وعلا- آلآهه، فأراد أن يقدم أول شيء ما هو أسبق قدما من ضروب آلآئه وأصناف نعمائه، وهي نعمة الدين، فقدم من نعمة الدين ما هو أعلى مراتبها وأقصى مراقيها وهو إنعامه

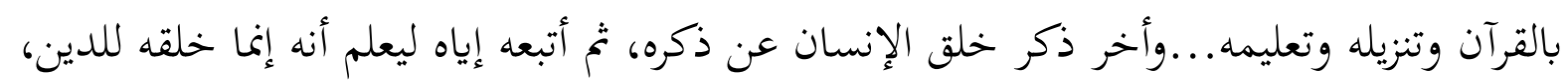

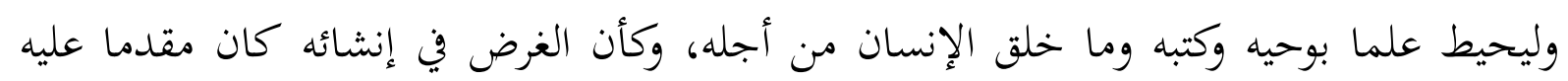

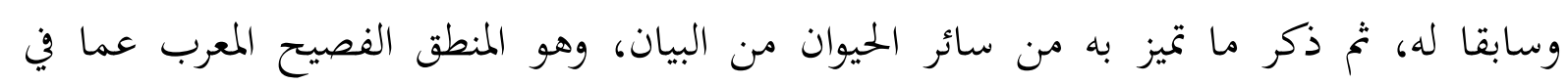
الضمير 25

\section{علم الساعة أو إسكاتولوجيا}

$$
\begin{aligned}
& \text { 242عبد الكريم الخطيب، التفسير القرآني للقرآن، (ط. 1:دار الفكر العربي: د. م.، } 1390 \text { هـ -1970 م)، ج. 5، } \\
& \text { https://vb.tafsir.net/tafsir44203/ (26 Juli 2018) ص. } \\
& 25 \text { جار الله محمود بن عمر الزخشري، الكشاف عن حقائق التنزيل وعيون الأقاويل في وجوه التأويل، تحقيقعادل أحمد }
\end{aligned}
$$

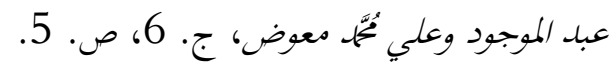


وأما أغراض أسلوب الجناس الناقص أو جناس الاشتقاق في قوله تعالى:

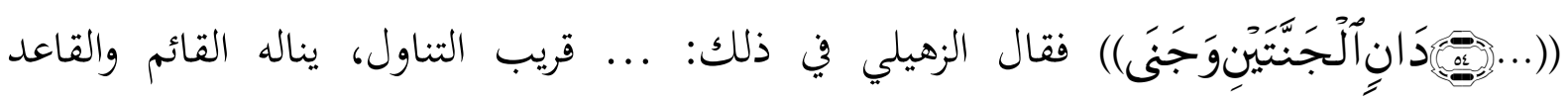

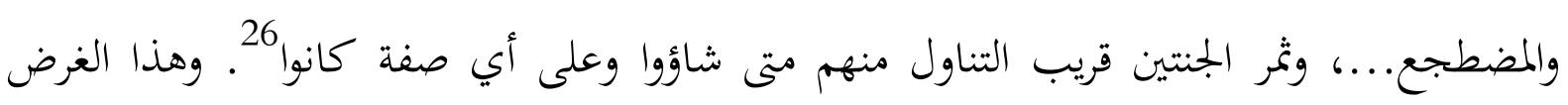
يتناسب مع حقيقة الجناس الذي فيه تقارب حروفه كما في هذه الآية الكريمة.

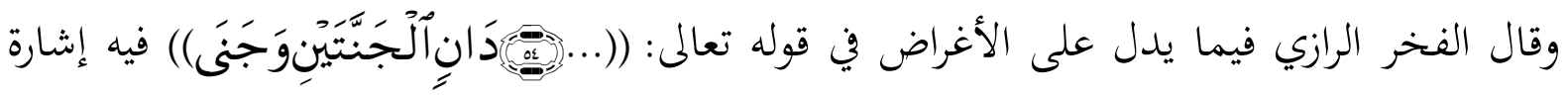
إلى مخالفة الجنة دار الدنيا من ثلاثة أوجه، أحدها: أن الثمرة في الدنيا على رءوس الشجرة والإنسان

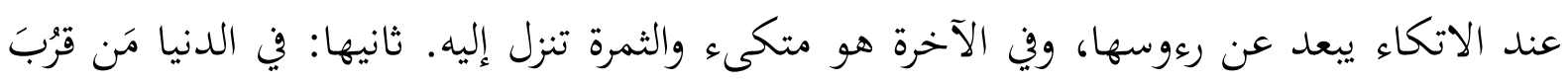

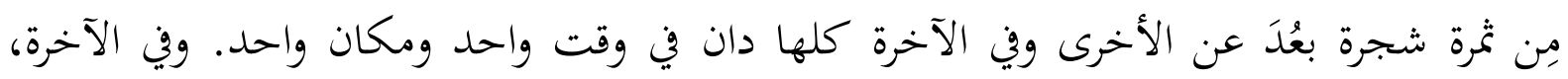

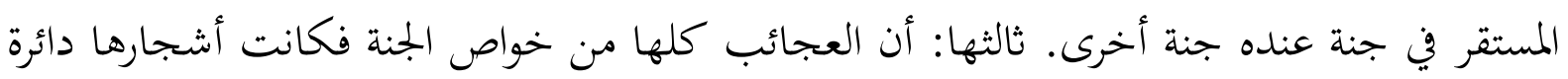
عليهم ساترة إليهم وهم ساكنون، على خلاف ما كان في الدنيا وجناتما، وفي الدنيا الإنسان متحرك ومطلوبه ساكن، وفيه الحقيقة وهي أن من لم يكسل ولم يتقاعد عن عبادة الله تعالى، وسعى في الد الدنيا

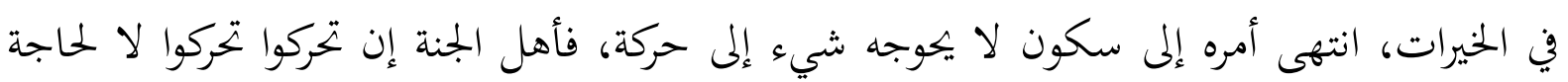

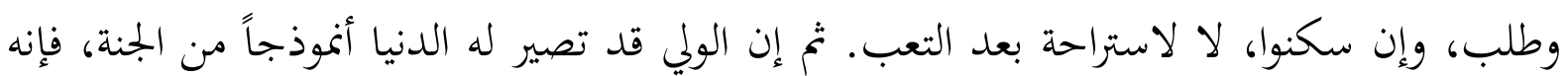

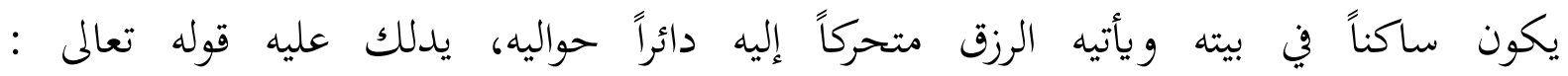

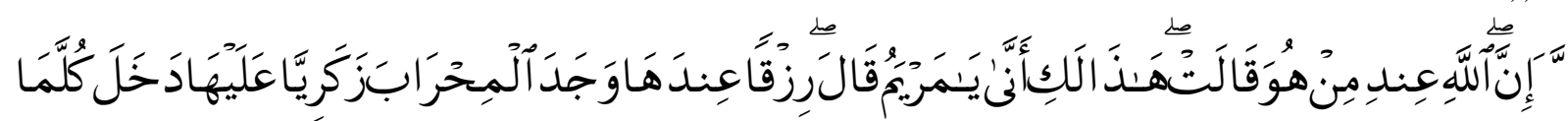

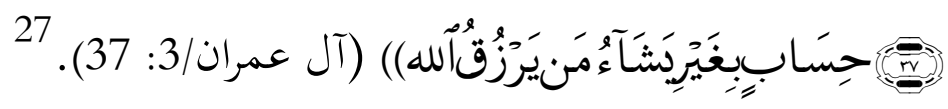


المحسنات اللفظبة في سورة الرحمن (دراسة تحليلية بلاغية)

يتكون مجموع المحسنات اللفظية في سورة الرحمن من أربع محسنات، وهي:1) السجع المرصع في موضع واحد،2) الجناس بنوعيه المماثل والناقص في ثلاثة مواضع، 3) وحسن الابتداء أو براعة إندات الاستهلال في موضع واحد،4) وحسن الاختتام أو مسك الختام في موضع واحد، فصار مجموع هذه ولنه العناصر البديعية اللفظية أربعة في ستة مواضع.

وأما أغراض المحسنات اللفظية في سورة الرحمن فتكون في أربعة أغراضو وهي: 1) الإعجاز اللغوي،

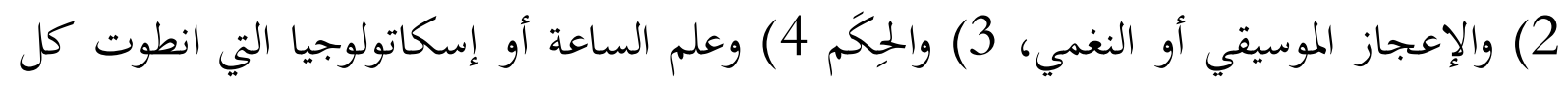
هذه الأغراض في مسميات رحمة الله وآلآئه.

\section{مراجع}

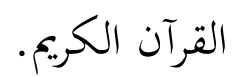

إبن عاشور، عُمَّمّ الطاهر. التحرير والثنوير. الدار التونيسية للنشر: تونس، 1984. https://archive.org/details/FP3667 (31 Mei 2018).

إبن مالك، بدر الدين. المصباح في المعاني والبيان والبديع. تحقيق حسني عبد الجليل يوسف.

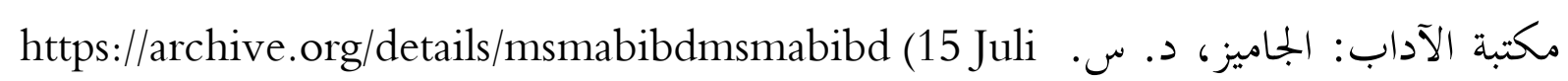
2018).

الأندلسي،أبو حيان نُمَّلّ بن يوسف. البحر المحيط. تحقيق عادل أحمد عبد الموجود. ط. 1 https://archive.org/details/FP10079FP دار الكتب العلمية: بيروت، 1413 هـ - 1993 م. (31 Mei 2018).

البقاعي، إبراهيم بن عمر. نظم الدرر في تناسب الآيات والسور. دار الكتاب الإسلامي: https://archive.org/details/FP3994 (28 Mei 2018) القاهرة، 1404 هـ - 1984 م. البيضاوي، عبد الله بن عمر. أنوار التنزيل ؤمرار التأويل. دار الكتاب الإسلامي: القاهرة، https://archive.org/details/TafsirBaydawi (30 Juni 2018) 1404 الجارم، علي ومصطفى أمين. البلاغة الواضحة .ط. 1; مكتبة البشرى: باكستان، 1431 هـ 
الرازي، فخر الدين تُحَّة بن عمر. التغسير الكبير ومغاتيح الغيب. ط. 1: دار الفكر: https://archive.org/details/mghtrazi (28 Mei 2018) بيروت، 1401 هـ - 1981 مرئ الزحيلي، وهبة. التنسير المنير في العقيدة والشريعة والمنهج. ط. 10; دار الفكر: دمشق، .http://ar.islamway.net/collection/12231 (27 Mei 2018) 1430 الزخشري،جار الله محمود بن عمر. الكشاف عن حقائق التننيل وعيون الأقاويل في وجوه

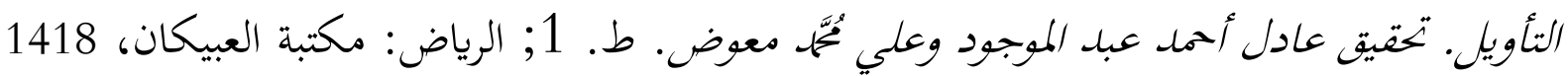
https://archive.org/details/Kashaf2 (30 Juni 2018). هـ 1998 م

السكاكي. مفتاح العلوم. تحقيق نعيم زرزور. ط. 2; بيروت: دار الكتب العلمية، 1407 هـ - 1987 م. السيوطي، الحافظ جلال الدين. إتمام الدراية لقراء النقاية. تحقيق إبراهيم العجور. ط. 1'; بيروت: (20)http://waqfeya.com/book.php?bid=10377 أبريل 2018 م).

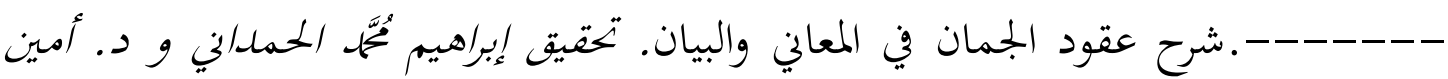

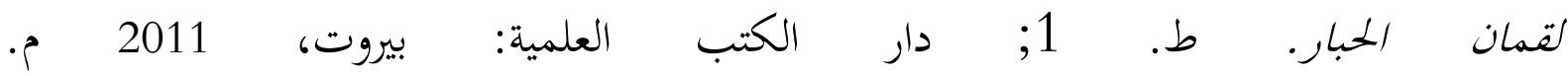
https://archive.org/download/charhoq...rhsytqdjmn.pdf (14 Juli 2018). الصابوني،يُمَّل علي. صغوة الثناسير. دار القرآن الكريم: بيروت، 1402 هـ - 1981 م. https://archive.org/details/Safwattafasir (31 Mei 2018). الطبري، مُحَّة بن جرير . جامع البيان عن تأويل آي القرآن. تحقيق بشار عواد معروف وعصام

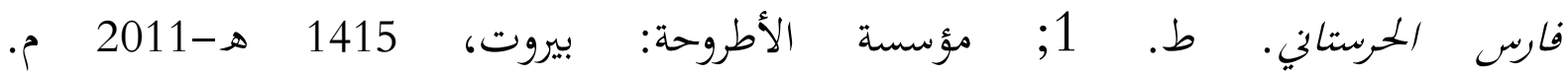
https://archive.org/details/WAQ17998 (14 Juli 2018).

عباس، تحسين فاضل وميثاق علي السلمي. "التكرار في الحكم والمواعظ في فج البلاغة دراسة ل دلالية" https://www.uokufa.edu.iq/journals/index.php/arll/article/view/6424. (24 2017) Juli 2018). 
الدحسنات اللفظبة في سورة الرحمن (دراسة تحلبلية بلاغية)

عمران. الأمر في سورة التوبة دراسة تحليلية من منظور علم المعاني .مجلة ديوان، ج. 4، الرقم

عوض6إبراهيم. سورة الرحمن دراسة بلاغية وأسلوبية. د. ن.: د. م.، 1438 هـ - 2016 م.

http://www.alukah..net/ library/0/109900/ (16 Juli 2018).

القزويني، الخطيب جلال الدين. الإيضاح في علوم البلاغة. تحقيق إبراهيم شمس الدين. ط.

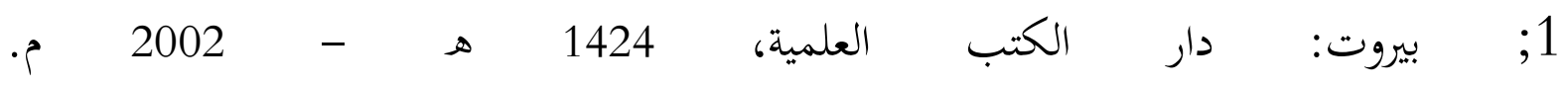

20 http://waqfeya.com/book.php?bid=2536 (20 أبريل 2018 م).

المصري، ابن أبي الإصبع. بديع القرآن. تحقيق حفني مُمَّم شرف. نضة مصر: د. م.، د. س.

https://kutub.me/kcDy1 (15 Juli 2018).

الميداني،عبد الرحمن. البلاغة العربية أسسها وعلومها وفنوغا. دم. دون. دن. دس.

https://archive.org/details/chucraet_moakt (26 Mei 2018).

الهانمي، أحمد. جواهر البلاغة في المعاني والبيان والبلديع. ط. 12; إندونيسيا: مكتبة دار

$$
\text { إحياء الكتب العربية، } 1379 \text { هـ - } 1960 \text { م. }
$$

الهرري، طُمَّمَ الأمين. حدائق الروح والريهان في روابي علوم القرآن. ط. 1; دار طرق النجاة:

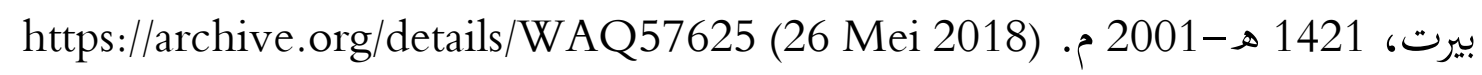

